\title{
The 2017 Saudi-Qatari crisis: The White House and The New York Times see two different events
}

\section{Anthony Moretti}

Robert Morris University (USA)

DOI: 10.30547/worldofmedia.2.2019.1

\begin{abstract}
The 2017 dispute between Saudi Arabia and Qatar provided the Trump administration an opportunity to demonstrate how it would conduct foreign policy and potentially alter the diplomatic relationships established with each country by its immediate predecessors. The dispute also allowed for an examination of how The New York Times would frame the conflict. This manuscript reviews the census of stories appearing in the main news section distributed by the newspaper from the beginning of the conflict through to the end of the 2017 calendar year. The results indicate the Trump administration's view of the conflict appeared to be simplified as a good actor and a bad actor, influenced by the president's affinity for one of the nations. The New York Times regularly highlighted the mistakes it believed the White House was making in addressing what it saw as a more complex dynamic between the two Middle Eastern nations.
\end{abstract}

\section{Keywords}

Saudi Arabia, Qatar, Middle East, framing, newspaper coverage, New York Times.

\section{Introduction}

On June 5, 2017, a simmering dispute between Saudi Arabia and Qatar exploded. On that date, Saudi Arabia, joined by Bahrain, Egypt, the Maldives, the United Arab Emirates and Yemen, cut ties with Qatar, in a move that 'created an immediate crisis for Qatar, whose only land border is with Saudi Arabia and which imports about 40 percent of its food from the Saudis' (Barnard \& Kirkpatrick, 2017). The Saudis closed their side of the Saudi-Qatari border and refused to allow any Qatar Airlines flights going to or coming from Qatar to

Corresponding author:

Anthony Moretti, Robert Morris University, 6001 University Blvd., Moon Township, PA, USA 15108

Email: moretti@rmu.edu 
fly over their airspace (Calder, 2017). Qataris in Saudi Arabia and two other nations were ordered to leave those countries (Al Arabiya, 2017). Saudi Arabia also demanded that Qatar-based Al Jazeera be shuttered because, in Riyadh's eyes, it had become too close to the Muslim Brotherhood (an enemy of Saudi Arabia) and 'advanced extremist or sectarian views on the channel' (Fahim, 2017).

This manuscript reviews two elements connected to what unfolded in that part of the Middle East. The coverage period began on June 5 and ended with the conclusion of the 2017 calendar year. First, public comments and statements coming from the White House about the crisis are examined. Second, this paper reviews reporting and editorials from The New York Times, long considered the newspaper of record in the United States, about the situation. The author recognizes as 2017 wore on attention was being paid to the Saudi-led effort to rout Houthis from nearby Yemen, and that media attention at times linked what was happening there to the dispute between Saudi Arabia and Qatar (Henderson, 2017). This manuscript does not explore the Saudi-Yemeni situation or any reaction it engendered from the White House.

Perhaps the best way to frame the Saudi-Qatar issue for unfamiliar audiences is to remind them that Saudi Arabia is the most prominent Sunni Muslim state throughout the Arab and Middle Eastern world, while Qatar is a Saudi rival and characterized, at least nominally, as allied with Iran (Walsh, 2017b), which has the largest Shia Muslim population in the region (BBC, 2013). Qatar is also home to Al Jazeera, a 24-hour news agency and 'the most popular news channel in the Arab world' (Carlstrom, 2017) and a perpetual critic of Saudi Arabia.

In May, 2017, and roughly one month before the blockade began, President Donald Trump made a state visit to Saudi Arabia, his first such trip as president. While there, The New York Times reported, he delivered a speech about terrorism, telling 'leaders of dozens of Muslim countries gathered there that he considered the kingdom a crucial ally in fighting terrorism and confronting Iran' (Hubbard \& Fisher, 2017). In Saudi Arabia, he articulated his belief that 'radical ideology' needed to come to an end and that the Saudi leadership had impressed upon him that Qatar was providing millions of dollars to terrorist groups (Wintour, 2017). Seeing Saudi Arabia as a critical ally in his vision of a so-called 'Arab NATO', the President knew the 'Saudi leadership was eager to do business' after years of frustration at the policies pursued by Barack Obama (Rogin, 2017). What the president failed to discuss was Saudi Arabia's hostile actions throughout the Middle East, actions equated to terrorism by its critics (Armstrong, 2014). One critic suggested Saudi Arabia is the 'fountainhead of Islamic extremism' and has 'lavishly financed' terrorism around the world (Butt, 2015). As the Saudi-Qatari 
dispute unfolded, Trump steadfastly refused to discuss any controversial Saudi actions as terrorism.

\section{Literature review}

Framing is a powerful influence in daily print and broadcast journalism. It leads to a decisive narrative about news events; once formed, the frame is difficult to break. Entman (2006) reported that frames developed from the words and images used by news agencies as they chronicled important events. Nelson et al. (1997, p. 222) stated that frames help 'to make sense of a broad array of information and events while suggesting a suitable course of action.' Dimitrova et al. (2005) added the emphasized elements of a story become more salient to the audience. An often-used frame, especially in international news, is crisis or conflict (Cozma \& Kozman, 2018; Elena, 2016; Semetko \& Valkenburg, 2000). Government sources are critical in this process of selecting frames (Entman, 2004); they regularly appear as supposedly credible news sources to discuss domestic and world events. The suggested credibility of these important actors gives their words legitimacy (Tuchman, 1973). Actions have responsibilities, and media frames, reinforced by sources, can dictate who is deemed to be the cause of a problem and who should be tasked to fix it (Iyengar, 1991).

Underscoring the selection of words, images, sources and ideas can be the unconscious absorption of assumptions that journalists make about the world around them and their audiences' acceptance of news stories (Hackett, 1984). Journalists and their employers also must consider cultural, political, societal and organizational factors in their development of frames (Kim et al. 2010).

These cultural attributes are integral in identifying and understanding societies, and people who believe they are similar to each other are more likely to relate to each other. By extension, those people who are considered different could be classified as threatening (Galtung \& Ruge, 1965; Salwen \& Garrison, 1989). Distance negatively affects this idea of who is, and who is not, different; when it does, stereotyping occurs. Shaheen (1985, p. 161) reminds us that the 'greater the distance we are from any group, including Arabs, the greater the reliance upon preconceived images about that group.' He adds that when it comes to Arabs and the Middle East, a firm stereotype in the United States is in place:

Many myths perpetrated by writers for television and film, novelists, cartoonists, and others promote false perceptions. Arabs are portrayed as extremely wealthy, as sex maniacs and white slavers. They are described as terrorists, their society as violent, and their religion, Islam, as radical. (p. 162) 
Perhaps worse, Shaheen finds plenty of examples of mainstream journalists employing language or imagery that equates the typical Arab or Middle Eastern man or woman as dangerous to the West.

Gentzgow \& Shapiro (2004) find the stereotypes cut both ways, with many people in the Arab and Middle Eastern world holding negative views about the United States. They suggest the culmination of that animosity became crystal clear when only half the people from that region who responded to a survey believed the Sept. 11, 2001, attacks were absolutely unjustified.

Well over a decade and a half since that September date, the hostile stereotypes have hardened: the Muslim terrorist in many American eyes; the crusading American in many Muslim eyes. The subsequent war on terror following Sept. 11 that began under the George W. Bush presidency, and the numerous terrorist incidents perpetrated by radical Muslim men and women all over the world have affirmed to many Americans this terrorist idea. The last three U.S. presidents have grappled with how to contain so-called radical Islam, a phrase that especially resonates with Americans on the right of the political spectrum (Abdelkader, n.d.).

Compounding the problem of stereotyping and anti-Muslim and anti-Arab sentiments evident in Western media reporting (Guzman, 2016; Morin, 2016; Polonska-Kimunguyi \& Gillespie, 2016; Powell, 2011) was the absence, for decades, of a powerful international broadcaster within the region disseminating Arab and Middle Eastern analysis and opinion locally and beyond. When Qatarbased Al Jazeera launched in November 1996, it quickly established a reputation for solid reporting and a lightning rod for criticism.

Lahlali (2011, p. 84) writes that 'the channel's chief aim' is to offer 'a platform for voiceless people.' According to Seib (2005, p. 601), on Al Jazeera, 'everything from the role of women to the competence of governments is addressed, often loudly.' He adds that Al Jazeera was largely ignored in the West until the aftermath of the Sept. 11 attacks. Its reporting about the attacks and especially the subsequent U.S.-led invasion of Iraq often conflicted with U.S. preferred themes, frustrating American officials eager to present a globally accepted argument that war was justified (Seib, 2005).

Al Jazeera also has made enemies in other Middle Eastern countries: Bahrain, Kuwait and Saudi Arabia have reacted negatively to the news agency's reporting. Pintak (2006) argues that the negative reaction should not be surprising because almost every government there historically has held a tight rein on the broadcast media. Pintak (2006, p. 71) adds that Saudi Arabian leaders were most disturbed by Al Jazeera because it 'not only impinged on their near-monopoly of pan-Arab media, but the station had the temerity to give voice to those who would question the House of Saud.' 
Kraidy (2013) argues Saudi officials find Al Jazeera troubling because it disseminates images that might call into question the strict piety and gender separation that undergirds Saudi Arabia. Hammond (2012, p. 190) calls this effort to narrow the parameters of approved commentary and appearance as the 'cordon sanitaire around Saudi Arabia in the Arab media, a sanitised zone where no news inimical to the realm of Al Saud can make its way through the purified information ether.'

The New York Times has long been considered a pre-eminent newspaper in the United States. Merrill (1968, p. 13) stated that an elite newspaper should be 'serious, concerned, intelligent and articulate,' and he argued The New York Times met such criteria. The newspaper also has been used by multiple scholars who examine U.S. media reporting of international events (Ramaprasad, 1987; McCoy, 1992; Goodman, 1998; Chang \& Zeldes, 2006; Luther \& Radovic, 2014). Despite its domestic and international accolades, it has not escaped criticism for its reporting from and about the Middle East. Barranco \& Shyles (1988, p. 255) found that the newspaper disseminated substantially more coverage about Israel than of its Arab and Muslim neighbors, with one effect being 'infecting the international news agenda with disfigured perceptions of the Mideast.' Zelizer et al. (2002) reported the newspaper differed from two other leading U.S. competitors in coverage of the early stages of the Intifada that began in 2000. Ha (2017) suggested that the newspaper's editorials too often framed the Arab Spring through an American lens, with a warning that American interests could be jeopardized if the movement had sustained success.

In summation, news frames, once established, quickly are equated with fact, most especially when they are created by powerful government officials and interests. American media often have endorsed the frame suggesting the Middle East is hostile to American interests and contributed to the stereotype that Muslims in that part of the world are eager to attack Western men and women. The New York Times has been criticized by researchers for an imbalance in reporting about the Middle East, and because of its laudatory record of international news coverage influences other news agencies as they report from and about the region.

\section{Methodology}

The coding period for this research began on June 5, 2017, when Saudi officials and several of their allies announced the severing of relations with Qatar. The coding period concluded with the end of the 2017 calendar year, so as to allow for a full examination of how The New York Times reported what was happening 
between the two nations, and how the Trump administration spoke of the situation throughout 2017.

This paper first identifies and analyzes all public statements disseminated by the White House that pertain to the Saudi Arabia-Qatar crisis. The author recognizes that the president discussed the crisis with other regional leaders; however, Saudi Arabia and Qatar were the main combatants in the dispute. As such, the president's interactions with representatives of those nations offered the best framework for examining how his thoughts, opinions or actions might have changed throughout the period under review.

The author retrieved all statements from the White House's Office of the Press Secretary website ${ }^{2}$ pertaining to the Saudi-Qatari crisis. In reverse chronology, the website lists all statements from the Trump administration. The author scrolled through each page on the website seeking the statements required for analysis. The keywords included 'Saudi Arabia' and 'Qatar', and the names of the countries' leaders. The researcher downloaded any statement that mentioned Saudi Arabia, Qatar, or one of its leaders and referenced the conflict between the two nations. These statements were then read to ensure they referred to telephone conversations or meetings with a Saudi Arabian or Qatari official. Those that met these criteria were used in this study.

This paper also reviews a census of stories and editorials relating to the Saudi Arabia and Qatar crisis that appeared in the main news section (Section A) of The New York Times. This section was the only one used because it offers the top national and international stories of the day. It also contains the editorial and op-ed pages. Four questions helped to determine whether to select a story or editorial from this section. Did the story or editorial reference Saudi Arabia and/or Qatar? Did it highlight the crisis from a Saudi and/or Qatari perspective? Did it analyze how the U.S. government was engaging with the leaders of those countries and others in the region as it addressed what was happening? Was $\mathrm{Al}$ Jazeera included anywhere in the story? The researcher does not dispute that cultural, athletic, social, educational and other issues might have been affected because of the Saudi-led decision to boycott Qatar; however, this paper reviews a narrow perspective: the U.S. response to the decision and how The New York Times framed the conflict and the Trump administration's response to it.

Using the ProQuest Newsstand database, the author separately entered 'Saudi Arabia' and then 'Qatar' into the search bar. The aforementioned June 5 and December 31, 2017, dates were included. Toward the bottom of the

${ }^{2}$ The White House`s Office of the Press Secretary website. Available at: https:// www.whitehouse.gov/briefing-room/press-briefings 
ProQuest Newsstand database homepage and under the 'Source type' column, 'Newspapers' was checked in order to limit the number of possible entries. Once that information was entered, the search advanced to a new page, where it was possible to find The New York Times under 'Publication title.'

Informed by the research of Hester (1973), Abdelkader (n.d.) and others, particular attention was paid to the official line emanating from the White House about the crisis; whether radical Islamists were accused of stoking the uncertainty; which nations the administration asserted were responsible for what was happening; and which nations the Trump administration believed were attempting to resolve it.

RQ1: Consistent with the idea of political leaders being aware of and responding to international crises, especially those that carry a perceived or real threat to their country, how did the White House publicly address the Saudi Arabia-Qatar issue?

Research by Entman (2006), Nelson et. al. (1997), Dimitrova et. al. (2005) and others on framing assisted in identifying RQ2.

RQ2: Consistent with research into framing, what narrative about the crisis formed within the pages of The New York Times over time? Was one nation seen as the cause of the dispute? Did the newspaper counter or support aspects of the crisis promulgated by the White House?

Research from Lahlali (2011) and Seib (2005) validates that Al Jazeera operates without government repression; nevertheless, as Hackett (1984) and Kim et. al. (2010) noted, journalists are influenced by political, societal and cultural norms as they perform their daily tasks. Recognizing that Qatar's norms differ from America's, would the U.S. newspaper support a legitimate news agency even when it operated in a country with values that often clash with America's?

RQ3: How often did The New York Times mention that Saudi Arabia and its allies demanded Qatar-based Al Jazeera be shut down, and did the newspaper rally in any way to support the news agency?

\section{Results}

The White House's database of public statements reports eleven separate items relating to the 2017 Saudi-Qatari crisis. More specifically, it indicates the president spoke to Saudi leaders six times and to their Qatari counterparts three times over the roughly seven-month period identified in this study. (Two other statements highlighted the president's conversations with leaders from more than one nation.)

In addition, thirty-six stories from The New York Times were coded in this research study. Saudi Arabia, much more so than Qatar, was of interest to The 
New York Times during this study period. Multiple reports from and about the Kingdom that had nothing to do with the dispute with Qatar were disseminated, though not coded. Using the search criteria mentioned in the methodology, Saudi Arabia appeared in the pages of The New York Times almost 230 times during the coding period. Qatar did almost 100 times.

RQ1: The statements from the White House consistently highlighted two somewhat simplified frames: President Trump supported Saudi Arabia because it wanted to rid terrorism from the Middle East. In line with this, nations in the region that sought to eliminate terrorism were America's friend. The second frame suggested Iran was the opposite of Saudi Arabia: a nation eager to foment terrorism. As such, the White House contended Iran was the hostile power in the Saudi-Qatari conflict, a known sponsor of terrorism and Qatar needed to consider the ramifications of remaining in Tehran's good graces.

On June 6, one day after the blockade was announced, President Trump spoke to Saudi Arabia's King Salman about the dispute with Qatar for the first time. The White House (2017g) official statement noted, 'The two leaders discussed the critical goals of preventing the financing of terrorist organizations and eliminating the promotion of extremism by any nation in the region.' One day later, The New York Times reported, 'The president also asked King Salman... to draw up a list of grievances for Qatar to address, according to a senior administration official' (Sanger, Landler, \& Schmitt, 2017). This story was one of only two that referenced phone calls or other direct efforts the president had made to engage with Saudi or Qatari leaders in addressing the crisis.

The next conversation between Trump and a Saudi leader took place two weeks later. On June 21, the White House (2017e) release stated, 'President Donald J. Trump ... [and] Crown Prince Mohamed bin Salman of Saudi Arabia discussed the priority of cutting off all support for terrorists and extremists, as well as how to resolve the ongoing dispute with Qatar...'

The president next spoke to a Saudi leader alone about one month later. According to that White House (2017h) statement, 'President Donald J. Trump ... [and King Salman bin Abdulaziz Al Saud of Saudi Arabia ... discussed recent diplomatic efforts to resolve the dispute with Qatar... In particular, the President emphasized the need to cut all funding for terrorism and discredit extremist ideology.'

It took another six weeks before the men spoke again. According to the White House (2017i), 'President Donald J. Trump ... [and] King Salman bin Abdulaziz Al Saud of Saudi Arabia... discussed the need to defeat terrorism, cut off terrorist funding, and combat extremist ideology... The two leaders also addressed the threat Iran poses to the region.' 
The two men next spoke about six weeks later:

'President Donald J. Trump spoke yesterday with King Salman bin Abdulaziz Al Saud of Saudi Arabia... President Trump... emphasized the importance of the Gulf Cooperation Council in countering Iran's destabilizing activities in Syria, Yemen, Iraq, and elsewhere in the region. The leaders agreed on the importance of the partnership between the United States and Saudi Arabia...' (The White House, 2017j)

They spoke again on November 4:

'President Donald J. Trump ... noted that the King and Crown Prince's recent public statements regarding the need to build a moderate, peaceful, and tolerant region are essential to ensuring a hopeful future for the Saudi people, to curtailing terrorist funding, and to defeating radical ideology...' (The White House, 2017k)

The president also spoke with King Salman on December 20, shortly after a ballistic missile attack in Saudi Arabia. The subsequent statement from the White House was not included in this study because it offered no indication that the two leaders spoke about Qatar.

The president did speak with the Qatari leadership on three occasions. The first conversation took place on June 7. According to the White House (2017a) statement,

'President Donald J. Trump spoke today with Amir Sheikh Tameem bin Hamad Al Thani of Qatar. The President emphasized the importance of all countries in the region working together to prevent the financing of terrorist organizations and stop the promotion of extremist ideology.'

The president did not speak to only the Qatari leadership again for more than three months, specifically on September 7. According to the White House (2017b) statement, 'President Donald J. Trump ... [and] Amir Tamim bin Hamad Al Thani of Qatar... discussed the continued threat Iran poses to regional stability.'

The men met face to face about two weeks later, when each was in New York for the United Nations General Assembly gathering. The White House (2017d) statement noted:

'President Donald J. Trump met today with Emir Tamim bin Hamad Al Thani of Qatar... The leaders also discussed the importance of resolving Qatar's ongoing dispute with its neighbors ... in order to promote regional stability and counter the threat of Iran. The President ... stressed the importance of taking additional steps to follow through on commitments from the Riyadh Summit to cut off funding for terrorists, discredit extremist ideology, and defeat terrorist groups.' 
According to these statements, the White House delivered a consistent, albeit simple, message to Qatari officials: The Qataris were supporting the wrong side in this dispute, and they needed to consider the potential ramifications of that decision.

Two other White House statements require attention. On July 2, the president spoke to three regional leaders. According to the White House (2017f) statement,

'President Donald J. Trump spoke separately today with King Salman bin Abdulaziz Al Saud of Saudi Arabia, Crown Prince Mohamed bin Zayed Al Nahyan of Abu Dhabi, and Emir Tamin bin Hamad Al Thani of Qatar. On the calls, President Trump addressed his concerns about the ongoing dispute between Qatar and some of its Gulf and Arab neighbors. He reiterated the importance of stopping terrorist financing and discrediting extremist ideology...'

A similar round of phone calls took place two months later. According to the White House (2017c) statement,

'President Donald J. Trump spoke separately today with Crown Prince Mohamed bin Salman Al Saud of Saudi Arabia, Crown Prince Mohammed bin Zayed Al Nahyan of the United Arab Emirates, and Amir Tameem bin Hamad Al Thani of Qatar. The President underscored that unity among the United States' Arab partners is essential to promoting regional stability and countering the threat of Iran. The President also emphasized that all countries must follow through on commitments from the Riyadh Summit to defeat terrorism, cut off funding for terrorist groups, and combat extremist ideology.'

This series of phone calls generated the second story from The New York Times directly connected to an effort by the president to solve the crisis. The newspaper reported on September 10 that the president's attempt "to break the stalemate that has divided the wealthiest countries in the Middle East ended in failure on Saturday, when leaders from Qatar and Saudi Arabia, after speaking by phone for the first time in months, exchanged dueling, contradictory statements" (Walsh, 2017c).

In summation to RQ1, the president participated in addressing the SaudiQatari crisis in its initial weeks, although the statements suggest he did little more than frame the conflict as one side was good and the other was evil. The Trump administration did not acknowledge any sort of crisis, a common Western-endorsed theme to international events, as noted by Cozma \& Kozman (2018) and others, opting instead for a simplified assessment that the U.S. had Saudi Arabia were doing what the world needed: isolating and weakening Iran. This frame is consistent with Iyengar's (1991) contention that framing allows for powerful actors, especially world leaders, to dictate who is causing problems 
and who should solve them. The White House statements, which almost always lacked detail beyond the basic information, did not stray from the president's contention that Saudi Arabia was fighting the good fight and Qatar needed to see Iran as a dangerous enemy to its regional neighbors. The summary statements (called readouts), however brief they are, of his phone calls or face-to-face meetings, indicate President Trump repeatedly affirmed support for Saudi Arabia to continue its pressure on Qatar, and its ally Iran, believing regional and world stability could follow. Put more bluntly, the public statements affirm the president viewed the Saudis and their allies as the good guys in this conflict and the Iranians as the bad guys. Over time, the lack of public statements about communication with Saudi, Qatari and regional leaders suggest the president's interest in the crisis appeared to wane. It is possible that his failed attempt at ending the crisis in September caused him to distance himself from further detailed involvement.

RQ2: The New York Times' reporting - in its news coverage and editorials chafed at the president's decision to solidly support Saudi Arabia, which, the paper noted, had not been an open and tolerant society for decades. The newspaper also questioned the White House frame that the regional conflict was merely between a benevolent actor and a malevolent actor. The newspaper's reporting also discussed how the president's position had limited any U.S. effort to resolve the dispute.

Of the thirty-six stories or editorials reviewed in this study, two frames dominated the newspaper's discourse.

Frame 1: The president's support for the Saudis did not indicate a full grasp of the situation in the Middle East, and his appreciation for the Saudi royal family contributed to his blind spot. Four examples of this theme are highlighted here.

- 'Mr. Trump, by strongly embracing the Saudis, pulled the gloves off a brawl that had long threatened to turn ugly. But it could also end up hurting American efforts to build broader coalitions in the region, and weaken an ally that has provided a vital base for the American military in its campaign against the Islamic State' (Barnard \& Kirkpatrick, 2017);

- 'Despite the convenience of this narrative [that paints Qatar as destabilizing the region because of its support for the Islamic State]... the more heinous sin for which Doha is being punished is its willingness to acknowledge that Iran occupies a position as an important regional power. [Nevertheless, the Trump administration] is obsessed with the twin threats of Iranian influence and "radical Islamic terror" (Barrett, 2017); 
- 'President Trump, who received a rapturous welcome in Riyadh [in May], welcomed the blockade of an American ally, a stunning policy reversal that seemingly happened overnight. On Twitter, he seemed to imply that the blockade had been his idea. But forcing hands can be risky' (Fisher, 2017);

- 'Mr. Trump sent his secretary of state, Rex Tillerson, to the region to sort out the mess. But among the monarchs of the Middle East, an underling's voice stood no chance of undoing the damage already done by his master's tweets' (Nasr, 2017).

Frame 2: The president's endorsement of the Saudi position vis- -vis Qatar was not shared by some of the most prominent people in his administration, and the difference of opinion often was on public display. Four examples illustrating this theme are mentioned here.

- 'Secretary of State Rex W. Tillerson and Defense Secretary Jim Mattis initially tried on Monday [June 5] to smooth over the rift, with Mr. Tillerson offering to play peacemaker and Mr. Mattis insisting [the Saudi decision] would have no effect on the campaign against the Islamic State' (Landler, 2017);

- "Mr. Tillerson called for a "calm and thoughtful dialogue" to resolve the deepening dispute among Sunni Muslim states in the Persian Gulf. Barely an hour later, Mr. Trump's comments were anything but that. He accused Qatar of being a "funder of terror at a very high level" and demanded that the tiny, energy-rich nation cut off that money flow to rejoin the circle of responsible nations' (Landler \& Gardiner, 2017);

- 'Mr. Trump has said he is backing Saudi Arabia and the United Arab Emirates because Qatar is "a funder of terror at a very high level." But his stance toward Qatar, which is host to the largest American air base in the region, has differed sharply from the positions of the Pentagon and State Department. The secretaries of defense and state have stayed neutral, urging unity against the common enemy of the Islamic State' (Kirkpatrick, 2017);

- 'The State Department on Tuesday issued a blistering critique of Saudi Arabia and other Persian Gulf countries for enforcing a two-week embargo against Qatar... The statement seemed to put President Trump and Secretary of State Rex W. Tillerson further at odds about who is to blame for the dispute, which threatens a host of American diplomatic and security priorities in the gulf' (Gardiner, 2017).

In summation to RQ2, The New York Times concluded President Trump was unable to look past his affinity for the leadership in Riyadh, preventing him 
and members of his administration from coming up with concrete proposals that might have been ended the conflict. The newspaper routinely noted the president either could not or would not accept the complexity to the dispute. His stance reduced American prestige in the region and neutered any opportunity for key members of his administration to come up with solutions to the crisis.

RQ3: The New York Times infrequently discussed Al Jazeera and the Saudi demand that it be closed; however, when the newspaper referred to the news channel, it always did in positive ways. The Saudi demand that Al Jazeera be shuttered was dropped on July 19, 2017 (Gladstone, 2017), mere weeks after it was ordered, thus reducing the amount of time the newspaper had to address this issue.

In one of its most forceful defenses of the news agency, The New York Times' editorial board wrote the following:

Saudi Arabia is hardly innocent when it comes to spreading Islamist extremism or supporting terrorist groups. In reality, by attacking Al Jazeera, the Saudis and their neighbors are trying to eliminate a voice that could lead citizens to question their rulers. Al Jazeera was the prime source of news as the Arab Spring rocked the Middle East in 2011 (The New York Times Editorial Board, 2017).

In other stories, the newspaper acknowledged that Al Jazeera was 'influential' (Walsh, 2017a), 'the region's most powerful megaphone' (Blinken, 2017), and used by Qatar 'to project soft power, promote allies and needle the Saudi royal family' (Fisher, 2017). The newspaper noted Al Jazeera's firm determination that it would not allow the Saudis to 'silence the freedom of expression in the region' (Hubbard, 2017).

In short, The New York Times affirmed whenever it could that Al Jazeera was an important bulwark against state-sponsored journalism within the Arab and Middle Eastern worlds, and it played an important role in ensuring its regional and broader audiences understood what was taking place throughout 2017.

\section{Conclusion}

There was a clear disconnect between the frames posited by President Trump and The New York Times when it came to telling American audiences about the dispute between Saudi Arabia and Qatar. According to the president, Saudi Arabia was an essential American ally in reining in terrorism, which Trump insisted was financed by Iran. According to the newspaper, Trump could not see the Saudi-Qatari dispute through the lens of two important Middle Eastern actors fighting to advance their prestige within the region. Instead, the newspaper's 
stories claimed the conflict served one purpose: isolating and weakening Iran while supporting a nation that rarely evinced Western values.

Recognizing how Trump railed against the 2015 Iranian nuclear deal (Begley, 2016), in which Iran promised to derail its nuclear ambitions in exchange for the lifting of billions of dollars' worth of sanctions against it, it comes as no surprise to Americans that Trump would view Iran as a dangerous regional and international force. In Trump's simplified global view, Iran had to be dealt with, and any nation that adopted this viewpoint was an immediate ally.

The New York Times repeatedly pushed back against this narrative. It reported that prominent voices within and outside the administration noted that Qatar was an important regional ally and home to America's largest military force in the region fighting the Islamic State. It added that Saudi Arabia seemed empowered to bully Qatar, with which it often sparred, because leaders in Riyadh seemed confident the president would do nothing to stop them. The newspaper noted more than once that Saudi Arabia was not a beacon of freedom and would want to tamp down such messages emanating from Doha, Qatar's capital city, and through Al Jazeera.

Berry (1990, p. 1) argued that U.S. news media agencies will refrain from criticizing a president's foreign policy plans until it becomes apparent the policy will not succeed. Arguing that 'journalists do not want a failing policy to continue' and will label a 'failure as a failure', Berry's hypothesis is American media believe in deference to the president. The results of this study suggest The New York Times' reporters afforded President Trump - just six months into his term - no such respect; within days of determining the Saudis should be supported for leading the blockade against Qatar, America's leading newspaper identified what it considered to be the futility and simplicity of what the president wanted. The newspaper questioned frames and stereotypes designed to present the Saudi-Qatari conflict as simple black and white, evil and good. It remained vigilant, or biased in eyes of any critics, in outlining both Saudi Arabia and Iran as nations that don't align with Western values. It validated that Sunni Islam's most powerful nation and Shia Islam's most powerful nation had competing visions for the region that the president refused to acknowledge. Using Berry's hypothesis, a case could be made that The New York Times' editors and reporters was conducting a kind-of shadow foreign policy by characterizing the president's program as failed before it had any chance to be analyzed.

Perhaps the most eye-opening report examined in this study came on July 5 , 2017. The New York Times' reporter Thomas Erdbrink examined how the crisis was being viewed by leaders in Iran. Erdbrink wrote, 'While Iran and Qatar share one of the largest gas fields in the world and have diplomatic relations, 
Qatar is of little or no strategic value to Iran' (Erdbrink, 2017). If it is true that the Iranians relished the positive public relations that came from framing the Saudi Arabia and Qatar dispute as a large Sunni-majority state attempting to weaken a much smaller nation, while noting President Trump was apparently quite happy to add to the bullying, then the winner of the Saudi-Qatari conflict was quite obvious: Iran.

\section{References}

ABDELKADER, E. (n.d.) The origins, evolution, and impact of the term 'radical Islam.' Penn Law. Available at: https://www.law.upenn.edu/live/news/6593the-origins-evolution-and-impact-of-the-term/news/international-blog.php

Al Aribaya. (2017). How many days to Qataris have to exit Saudi Arabia, the UAE and Bahrain? Available at: http://english.alarabiya.net/en/News/ gulf/2017/06/05/How-many-days-do-Qataris-have-to-leave-Saudi-ArabiaUAE-and-Bahrain-.html

ARMSTRONG, K. (2014). Wahhabism to ISIS: How Saudi Arabia exported the main source of global terrorism. Available at: https://www.newstatesman. com/world-affairs/2014/11/wahhabism-isis-how-saudi-arabia-exportedmain-source-global-terrorism

BARNARD, A. \& KIRKPATRICK, D. D. (2017). 5 Arab nations move to isolate Qatar, putting the U.S. in a bind. Available at: https://www.nytimes. com/2017/06/05/world/middleeast/qatar-saudi-arabia-egypt-bahrainunited-arab-emirates.html

BARNARD, A. \& KIRKPATRICK, D.D. (2017). 5 Arab nations put U.S. in jam as they move to isolate Qatar. Available at: https://reddog.rmu.edu:3479/docv iew/1906038946/2AB947046F2348A5PQ/1 ?accountid =28365

BARRANCO, D. \& SHYLES, L. (1988). Arab vs. Israeli news coverage in The New York Times, 1976 and 1984. Journalism and Mass Communication Quarterly, 65, 178-181, 255.

BARRETT, R. (2017). Qatar in the naughty corner: Commentary. Available at: https://reddog.rmu.edu:3479/usnews/docview/1906791413/52AA19AE BA9D4C0CPQ/8? accountid $=28365$

BEGLEY, S. (2016). Read Donald Trump's speech to AIPAC. Available at: http://time.com/4267058/donald-trump-aipac-speech-transcript/

BLINKEN, A. (2017). The mirage of an Arab alliance. Available at: https:// reddog.rmu.edu:3479/docview/1911073086/C6C61F360C24665PQ/19?acco untid $=28365$

BBC (2013). Sunnis and Shia in the Middle East. Available at: https://www. bbc.com/news/world-middle-east-25434060 
BERRY, N. (1990). Foreign policy and the press: An analysis of New York Times' coverage of U.S. foreign policy. New York: Greenwood Press.

BUTT, Y. (2015). How Saudi Wahhabism is the fountainhead of Islamist terrorism. Available at: https://www.huffingtonpost.com/dr-yousaf-butt-/ saudi-wahhabism-islam-terrorism_b_6501916.html

CALDER, S. (2017). Qatar Airways hit by airspace ban as diplomatic row intensifies. Available at: https://www.independent.co.uk/travel/news-andadvice/qatar-airways-airspace-ban-flights-grounded-diplomatic-row-saudiarabia-bahrain-egypt-uae-a7774636.html

CARLSTROM, G. (2017). What's the problem with Al Jazeera? Available at: https://www.theatlantic.com/international/archive/2017/06/al-jazeeraqatar-saudi-arabia-muslim-brotherhood/531471/

CHANG, K. K. \& ZELDES, G. A. (2006). Three of four newspapers studied favor Israeli instead of Palestinian sources. Newspaper Research Journal, 27, 84-90.

CHANG, T. K. \& LEE, J.W. (1992). Factors affecting gatekeepers' selection of foreign news: A national survey of newspaper editors. Journalism Quarterly, 69, 554-561.

COZMA, R. \& KOZMAN, C. (2018). The Syrian crisis in U.S. and Lebanese newspapers: A cross-national analysis. International Communication Gazette, 80, 185-204.

DIMITROVA, D., KAID, L., WILLIAMS, A. \& TRAMMELL, K. (2005). War on the web: The immediate news framing of Gulf War II. Harvard International Journal of Press/Politics, 10, 22-44.

ELENA, M. (2016). Framing international media in the face of social movements: CNN and Al-Jazeera English in the fall of Morsi. Communication and Society, 29, 119-130.

ENTMAN, R. (2006). Framing U.S. coverage of international news: Contrasts in narratives of the KAL and Iran air incidents. Journal of Communication, 41, 6-27.

ENTMAN, R. (2004). Projections of power: Framing news, public opinion, and U.S. foreign policy. Chicago: University of Chicago Press.

ERDBRINK, T. (2017). Arab rift with Qatar is welcome in Tehran. Available at: https://reddog.rmu.edu:3479/usnews/docview/1915720342/70C6835A2 55E4617PQ/54? accountid $=28365$

FAHIM, K. (2017). Demands by Saudi-led Arab states for Qatar include shuttering Al Jazeera. Available at: https://www.washingtonpost.com/ world/middle_east/saudi-led-arab-states-submit-demands-to-qatarincluding-shuttering-of-al-jazeera/2017/06/23/d9d2711a-580e-11e7-9e18968f6ad1e1d3_story.html?utm_term $=.4 \mathrm{e} 581 \mathrm{a} 5 \mathrm{~b} 0 \mathrm{c} 46$ 
FISHER, M. (2017). How the Saudi-Qatar rivalry, now combusting, reshaped the Middle East. Available at: https://reddog.rmu.edu:3479/usnews/docview /1908630141/52AA19AEBA9D4C0CPQ/14? accountid $=28365$

GALTUNG, J. \& RUGE, M. H. (1965). The structure of foreign news. Journal of Peace Research, 2, 64-91.

GARDINER, H. (2017). State Dept. lashes out over Qatar embargo. Available at: https://reddog.rmu.edu/login?url=https://search.proquest.com/docview $/ 1911476663$ ? accountid $=28365$

GENTZKOW, M. A. \& SHAPIRO, J. M. (2004). Media, Education and AntiAmericanism in the Muslim World. The Journal of Economic Perspectives, 18(3), 117-133.

GLADSTONE, R. (2017). Countries that cut Qatari ties ease stance. Available at: https://reddog.rmu.edu:3479/docview/1919850101/C6C61F360C24665 $\mathrm{PQ} / 11$ ? accountid $=28365$

GOODMAN, R. S. (1998). How two papers covered president and congress in China trade controversy. Newspaper Research Journal, 19, 40-57.

GUID RE, J. A. (2008). Understanding the media's language of war. Middle Eastern Studies, Vol. 44(6), 993-1007.

GUZMAN, A. (2016). Evolution of news frames during the 2011 Egyptian revolution: Critical discourse analysis of Fox News's and CNN's framing of protesters, Mubarak, and the Muslim Brotherhood. Journalism and Mass Communication Quarterly, 93, 80-98.

HA, J.S. (2017). Tailoring the Arab Spring to American values and interests: A framing analysis of U.S. elite newspapers' opinion pieces. International Communication Gazette, 79, 276-297. Available at: http://reddog.rmu. edu:2721/doi/pdf/10.1177/1748048516689178

HACKETT, R. (1984). Decline of a paradigm? Bias and objectivity in news media studies. Critical Studies in Mass Communication, 1, 229-259.

HAMMOND, A. (2012). The Islamic utopia: The illusion of reform in Saudi Arabia. London: Pluto Press.

HENDERSON, S. (2017). How the war in Yemen explains the future of Saudi Arabia. Available at: https://www.theatlantic.com/international/ archive/2017/11/saudi-arabia-iran-yemen-houthi-salman/545336/

HUBBARD, B. (2017). Arab nations present demands to Qatar, including that it close down Al Jazeera. Available at: https://reddog.rmu.edu:3479/usnews/ docview/1962079443/E8FA89AB64D444B9PQ/48? accountid =28365

HUBBARD, B. \& FISHER, I. (2017). Trump's Saudi Arabia trip figures into plan for Palestinian deal. Available at: https://www.nytimes.com/2017/05/23/ world/middleeast/trump-trip-saudi-arabia-palestinians.html 
IYENGAR, S. (1991). Is anyone responsible? How television frames political issues. Chicago, IL: University of Chicago Press.

KIM, S. H., CARVALHO, J. P. \& DAVIS, A. G. (2010). Talking about poverty: News framing of who is responsible for causing and fixing the problem. Journalism and Mass Communication Quarterly, 87, 563-581.

KIRKPATRICK, D. (2017). Trump's business ties in Persian Gulf raise questions about conflict. Available at: https://reddog.rmu.edu/login?url=https:// search.proquest.com/docview/1910566607?accountid $=28365$

KRAIDY, M. (2013). Saudi-Islamist rhetoric about visual culture. In HAUGBOLLE, C. G. (Ed.), Visual culture in the modern Middle East (pp. 275292). Bloomington, IN: Indiana University Press.

LAHLALI, E. M. (2011). Contemporary Arab broadcast media. Edinburgh, U.K.: University Press.

LANDLER, M. (2017). Trump treads into feud between Qatar and Saudis. Available at: https://reddog.rmu.edu:3479/usnews/docview/1906329834/5 2AA19AEBA9D4C0CPQ/4?accountid $=28365$

LANDLER, M. \& GARDINER, H. (2017). Trump's diplomatic turns jolt some, ease others. Available at: https://reddog.rmu.edu:3479/usnews/docview/190 7673458/52AA19AEBA9D4C0CPQ/9?accountid $=28365$

LUTHER, C. A. \& RADOVIC, I. (2014). Newspapers frame Julian Assange differently. Newspaper Research Journal, 35, 64-81.

MCCOY, T. (1992). The New York Times' coverage of El Salvador. Newspaper Research Journal, 13, 67-84.

MERRILL, J. C. (1968). The elite press. New York: Pitman Publishing Company.

MORIN, A. (2016). Framing terror: The strategies newspapers use to frame an act as terror or crime. Journalism \& Mass Communication Quarterly, 93, 9861005.

NASR, V. R. (2017). Trump's gift to Putin in the Mideast. Available at: https://reddog.rmu.edu:3479/usnews/docview/1919589745/237647C77BF 4F02PQ/76? accountid $=28365$

NELSON, T, OXLEY, Z. \& CLAWSON, R. (1997). Toward a psychology of framing effects. Political Behavior, 19, 221-246. Available at: http://reddog. rmu.edu:2061/eds/pdfviewer/pdfviewer?vid=1\&sid=3dfc3309-eedf-4eb9944a-9951d19d87bf\%40sessionmgr4006

New York Times Editorial Board (2017, June 22). Misguided attacks on Al Jazeera. Available at: https://reddog.rmu.edu:3479/docview/1912037269/9 EE6B9FCE68F4A68PQ/1? accountid $=28365$

PINTAK, L. (2006). Reflections in a bloodshot lens: America, Islam and the war of ideas. London: Pluto Press. 
POLONSKA-KIMUNGUYI, E. \& GILLESPIE, M. (2016). Terrorism discourse on French international broadcasting: France 24 and the case of Charlie Hebdo attacks in Paris. European Journal of Communication, 31, 568-583.

POWELL, K. A. (2011). Framing Islam: An analysis of media coverage of terrorism since 9/11. Communication Studies, 62, 90-112.

RAMAPRASAD, J. (1987). Pre-, during and post-censorship coverage of India by The New York Times. Newspaper Research Journal, 9, 19-29.

ROGIN, J. (2017). Trump to unveil plans for an 'Arab NATO' in Saudi Arabia. Available at: https://www.washingtonpost.com/news/josh-rogin/ wp/2017/05/17/trump-to-unveil-plans-for-an-arab-nato-in-saudi-arabia/

SALWEN, M. \& GARRISON, B. (1989). Press freedom and development: U.S. and Latin American views. Journalism Quarterly, 66, 87-92.

SANGER, D., LANDLER, M. \& SCHMITT, E. (2017). Trump has busy day in vortex of Middle East relations. Available at: https://www.nytimes. com/2017/06/07/world/middleeast/trump-qatar-saudi-arabia-middle-east

SEIB, P. (2005). Hegemonic no more: Western media, the rise of Al-Jazeera, and the influence of diverse voices. International Studies Review, 601-615.

SEMETKO, H. \& VALKENBURG, P. (2000). Framing European politics: A content analysis of press and television news. Journal of Communication, 50, 93-109.

SHAHEEN, J. G. (1985). Media coverage of the Middle East: Perception and foreign policy. The Annals of the American Academy of Political and Social Science, 160-175.

SHAPIRO, M. A. (2004). Media, education and anti-Americanism in the Muslim world. The Journal of Economic Perspectives, 117-133.

The White House (2017a). Readout of President Donald J. Trump's call with Amir Sheikh Tameem Bin Hamad Al Thani of Qatar. Available at: https://www. whitehoomuse.gov/the-press-office/2017/06/07/readout-president-donald-jtrumps-call-amir-sheikh-tameem-bin-hamad-al

The White House (2017b). Readout of President Donald J. Trump's call with Amir Tamim bin Hamad Al Thani of Qatar. Available at: https://www. whitehouse.gov/the-press-office/2017/09/08/readout-president-donald-jtrumps-call-amir-tamim-bin-hamad-al-thani

The White House (2017c). Readout of President Donald J. Trump's call with Amir Tamim bin Hamad Al Thani of Qatar. Available at: https://www. whitehouse.gov/the-press-office/2017/09/08/readout-president-donald-jtrumps-call-amir-tamim-bin-hamad-al-thani

The White House (2017d). Readout of President Donald J. Trump's meeting with Amir Tamim bin Hamad Al Thani of Qatar. Available at: https://www. 
whitehouse.gov/the-press-office/2017/09/20/readout-president-donald-jtrumps-meeting-emir-tamim-bin-hamad-al-thani

The White House (2017e). Readout of President Donald J. Trump's call with Crown Prince Mohamed bin Salman of Saudi Arabia. Available at: https://www. whitehouse.gov/the-press-office/2017/06/21/readout-president-donald-jtrumps-call-crown-prince-mohamed-bin-salman

The White House (2017f). Readout of President Donald J. Trump's calls with Gulf State Leaders. Available at: https://www.whitehouse.gov/the-pressoffice/2017/07/02/readout-president-donald-j-trumps-calls-gulf-state-leaders

The White House (2017g). Readout of President Donald J. Trump's call with King Salman Bin Abdulaziz Al Saud of Saudi Arabia. Available at: https://www. whitehouse.gov/the-press-office/2017/06/06/readout-president-donald-jtrumps-call-king-salman-bin-abdulaziz-al-saud

The White House (2017h). Readout of President Donald J. Trump's call with King Salman of Saudi Arabia. Available at: https://www.whitehouse.gov/the-pressoffice/2017/07/14/readout-president-donald-j-trumps-call-king-salman-saudi-arabia

The White House (2017i). Readout of President Donald J. Trump's call with King Salman Bin Abdulaziz Al Saud of Saudi Arabia. Available at: https://www. whitehouse.gov/the-press-office/2017/08/30/readout-president-donald-jtrumps-call-king-salman-bin-abdulaziz-al-saud

The White House (2017j). Readout of President Donald J. Trump's call with King Salman bin Abdulaziz Al Saud of Saudi Arabia. Available at: https://www. whitehouse.gov/the-press-office/2017/10/15/readout-president-donald-jtrumps-call-king-salman-bin-abdulaziz-al-saud

The White House (2017k). Readout of President Donald J. Trump's call with King Salman of Saudi Arabia. Available at: https://www.whitehouse.gov/ the-press-office/2017/11/05/readout-president-donald-j-trumps-call-kingsalman-saudi-arabia

TUCHMAN, G. (1973). Making news by doing work: Routinizing the unexpected. American Journal of Sociology, 79, 110-131.

WALSH, D. (2017a). Qatar's riches soften blow of blockade, for now. Available at: https://reddog.rmu.edu:3479/docview/1915225307/C6C61F36 0C24665PQ/13? accountid $=28365$

WALSH, D. (2017b). Qatar restores full relations with Iran, deepening Gulf feud. Available at: https://www.nytimes.com/2017/08/24/world/ middleeast/qatar-iran-boycott-saudi-arabia.html

WALSH, D. (2017c). Trump's attempt to end the Saudi-Qatar stalemate ends in recriminations. Available at: https://reddog.rmu.edu:3479/usnews/docvie $\mathrm{w} / 1936960475 / 310890333$ AED406APQ/102? accountid=28365 
WINTOUR, P. (2017). Donald Trump tweets support for blockade imposed on Qatar. Available at: https://www.theguardian.com/world/2017/jun/06/ qatar-panic-buying-as-shoppers-stockpile-food-due-to-saudi-blockade

ZELIZER, B., PARK, D. \& GUDELUNAS, D. (2002). How bias shapes the news: Challenging The New York Times' status as a newspaper of record in the Middle East. Journalism, 3, 283-307. 